\title{
Pig Compost Use on Zinc and Copper Concentrations in Soils and Corn Plants
}

\author{
Juan Hirzel1, Ingrid Walter ${ }^{2}$ \\ ${ }^{1}$ Instituto de Investigaciones Agropecuarias (INIA), Santiago, Chile \\ ${ }^{2}$ Consultor Internacional, Madrid, Spain \\ Email: jhirzel@inia.cl, inwal@hotmail.com
}

Received 21 January 2015; accepted 7 March 2015; published 10 March 2015

Copyright (C) 2015 by authors and Scientific Research Publishing Inc.

This work is licensed under the Creative Commons Attribution International License (CC BY). http://creativecommons.org/licenses/by/4.0/

(c) (i) Open Access

\begin{abstract}
The use of pig compost (PC) in agricultural land has increased in Chile in the last years. This organic amendment is a valuable nutritional source for crops, but its applying must be done in a controlled manner since it exhibited high copper $(\mathrm{Cu})$ and zinc $(\mathrm{Zn})$ concentrations. A short-term field experiment was conducted out to study the effects of increasing PC rates on the production and quality corn crop in two soils located at south central Chile. Five treatments were evaluated: control without fertilization (C), conventional fertilization (CF) $\left(350 \mathrm{~kg} \mathrm{~N} \mathrm{ha}^{-1}\right)$, and three increas-

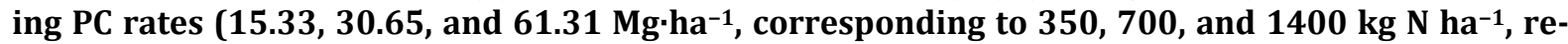
spectively) in a split plot design with four replicates. The overall results indicated that dry matter production, grain yield, and plant $\mathrm{Zn}$ and $\mathrm{Cu}$ concentrations were similar among fertilization sources and rates. Extractable soil Zn concentration exhibited a rate-related increase of PC in both locations, while $\mathrm{Cu}$ concentration exhibited this behavior only at the soil located in Chillan. Nevertheless, the values obtained were below of those considered phytotoxic levels. Therefore, the contribution of $\mathrm{Zn}$ and $\mathrm{Cu}$ through PC applying at different rates to the soils studied showed a slight affect in soil extractable $\mathrm{Zn}$ and $\mathrm{Cu}$ values without negatively effects on quantity and quality corn crop. The organic amendment applied can be a good and cheaper substitute to conventional fertilization, although further monitoring of $\mathrm{Zn}$ and $\mathrm{Cu}$ soil levels should be carried out to avoid any environmental risk.
\end{abstract}

\section{Keywords}

Pig Compost, Corn Crop, Zinc and Copper in Plant, Extractable Soil Zinc and Copper

\section{Introduction}

Pig compost, known as "biostabilized" in Chile, is derived from the pork industry; Chile produced approx- 
imately 300,000 Mg in 2008. This product is characterized by its high $\mathrm{Cu}$ and $\mathrm{Zn}$ concentrations which do not comply with the limits indicated by the Chilean Compost Regulation [1]. Despite the fact that this organic amendment is an important nutritional source for agricultural crops, it has a comparatively lower cost than conventional fertilizers [2] [3] just like amendments derived from other types of meat production [4]-[6]. In contrast inorganic fertilizers, the organic amendments have high organic matter content and can be used as source of slow-release nitrogen. Therefore, agricultural production systems that use these amendments contribute to improving soil physical, chemical, and biological properties [4] [7]-[9]. However, the net supply rate of certain nutrients, such as nitrogen $(\mathrm{N})$, is lower than the rate produced by conventional fertilizers [6] [10] [11]. In many cases, this situation has led farmers to increase the applied amendment rate to compensate $\mathrm{N}$ in the crop; this fact could cause certain environmental risks. The increment in the concentration of other elements generates potential health risk since they can enter the food chain or could have a negative effect on the plant development [12]-[14]. Heavy metals, such as $\mathrm{Cu}$ and $\mathrm{Zn}$, are two of these elements; their high rates in the PC can affect crop yield through direct effects on the plant or indirect effects derived from soil nutrient antagonism [12] [15]-[17]. In this respect, several works about the effect of organic amendments on heavy metals in plant and soil had been reported in the world [12] [15]-[18]. Moreover, for the Chilean conditions, there is not information published.

Therefore, in order to contribute to a better knowledge of using PC and its effects on a very important crop for world food supply, as well as for Chilean agriculture, the objective of this study was to evaluate the use of increasing PC rates on corn production, $\mathrm{Zn}$ and $\mathrm{Cu}$ concentrations in plant tissues, and the extractable concentration of these elements in the soil.

\section{Materials and Methods}

\subsection{Experimental Sites}

Two experiments were conducted in south central Chile with the Divino-SEMAMERIS corn hybrid during the 2010-2011 season to evaluate the effect of increasing PC rates and the associated contribution of $\mathrm{Cu}$ and $\mathrm{Zn}$. The locations were Chillán ( $36^{\circ} 36^{\prime} \mathrm{S}, 71^{\circ} 54^{\prime} \mathrm{W}$ ) with a silty loam soil (Melanoxerands) [19] [20] and Talca $\left(35^{\circ} 23.279\right.$ 'S, $71^{\circ} 36.57^{\prime} \mathrm{W}$ ) with a clay loam soil (Ultic Haploxerolls) [19] [21]. The crop in both locations was fertilized with the following treatments: 1) Control without fertilization (C); 2) Conventional fertilization (CF) N, phosphorus $(\mathrm{P})$, and potassium $(\mathrm{K})$ with known sources (urea, triple superphosphate, muriate of potash) at rates equal to PC contribution for an equivalent rate of $350 \mathrm{~kg} \mathrm{~N} \mathrm{ha}^{-1}$; 3) PC at $\mathrm{N}$ rates equivalent to $350 \mathrm{~kg} \cdot \mathrm{ha}^{-1}$ (15.33 $\mathrm{Mg} \cdot \mathrm{ha}^{-1}$ ) (N: $\mathrm{P}_{2} \mathrm{O}_{5}: \mathrm{K}_{2} \mathrm{O}$ ratio of 1:1.44:0.49); 4) $\mathrm{PC}$ at $\mathrm{N}$ rates equivalent to $700 \mathrm{~kg} \cdot \mathrm{ha}^{-1}\left(30.65 \mathrm{Mg} \cdot \mathrm{ha}^{-1}\right.$ ); 5 ) PC at $\mathrm{N}$ rates equivalent to $1400 \mathrm{~kg} \cdot \mathrm{ha}^{-1}\left(61.31 \mathrm{Mg} \cdot \mathrm{ha}^{-1}\right)$. The experimental design was split plot with four replicates in both locations and where the main plot corresponded to the location and the subplot to the fertilization treatment. Each plot within a block was $5 \mathrm{~m}$ long $\times 5 \mathrm{~m}$ wide with five rows of corn drilled at $0.70 \mathrm{~m}$ row spacing. The chemical characteristics of PC used in both experiments are shown in Table 1, whereas the chemical characteristics of both soils are shown in Table 2 .

The climate in both locations is Mediterranean with high temperatures and low rainfall during summer and lower temperatures and high rainfall during winter. The accumulated rain fall in Chillán was 776 mm, which was concentrated between May and October along with an annual evaporation of $1275 \mathrm{~mm}$ and average temperature of $13.0^{\circ} \mathrm{C}$. On the other hand, accumulated rainfall in Talca was $750 \mathrm{~mm}$, which was concentrated between May and September along with an annual evaporation of $1360 \mathrm{~mm}$ and average temperature of $14.6^{\circ} \mathrm{C}$. The trial site in both locations had been cropped with corn in previous years.

\subsection{Crop Husbandry}

All plots were cultivated to optimize crop growth according to standard agronomic practices for corn in central Chile. The trial site was plowed each year during the winter. The soil was prepared with conventional tillage equipment to establish an acceptable seedbed. Seeds were drilled with a disinfected standard drill. After emergence, weeds were controlled with a combination of herbicides depending on the observed weed pressure. The initial plant population for Chillán and Talca was 108,600 and 112,200 plants· ha ${ }^{-1}$, respectively.

The crop in Chillán was sowing on 21 October 2010 and grain harvested on 15 April 2011. The dates for these activities in Talca were 15 October 2010 and 2 April 2011, respectively. Whole plant moisture was approximately $15 \%$ at grain maturity. Pig compost was previously applied at sowing and for CF; P and K were applied at sowing and $\mathrm{N}$ was applied $40 \%$ at sowing and $60 \%$ at the 6 -leaf stage. For whole plant or grain harvest 
Table 1. Physico-chemical characteristics of pig compost (PC) applied in both experiments.

\begin{tabular}{|c|c|}
\hline Determined parameter & Values \\
\hline Moisture (\%) & 46.9 \\
\hline $\mathrm{pH}_{\text {in water (1:5) }}$ & 8.9 \\
\hline $\mathrm{EC}\left(\mathrm{dS} \cdot \mathrm{m}^{-1}\right)$ & 7.4 \\
\hline $\mathrm{OM}\left(\mathrm{g} \cdot \mathrm{kg}^{-1}\right)$ & 646.1 \\
\hline $\mathrm{C} / \mathrm{N}$ ratio & 8.7 \\
\hline Total C $\left(\mathrm{g} \cdot \mathrm{kg}^{-1}\right)$ & 374.4 \\
\hline Total N $\left(\mathrm{g} \cdot \mathrm{kg}^{-1}\right)$ & 43.0 \\
\hline Ammonia $\mathrm{N}\left(\mathrm{mg} \cdot \mathrm{kg}^{-1}\right)$ & 1.69 \\
\hline Nitric N (mg $\left.\cdot \mathrm{kg}^{-1}\right)$ & 3.47 \\
\hline Total P $\left(\mathrm{g} \cdot \mathrm{kg}^{-1}\right)$ & 27.1 \\
\hline Total K $\left(\mathrm{g} \cdot \mathrm{kg}^{-1}\right)$ & 17.7 \\
\hline Total Ca $\left(\mathrm{g} \cdot \mathrm{kg}^{-1}\right)$ & 32.9 \\
\hline Total Mg $\left(\mathrm{g} \cdot \mathrm{kg}^{-1}\right)$ & 15.3 \\
\hline Total Na $\left(\mathrm{g} \cdot \mathrm{kg}^{-1}\right)$ & 6.5 \\
\hline Total Fe (mg $\left.\cdot \mathrm{kg}^{-1}\right)$ & 1326 \\
\hline Total Mn (mg $\left.\cdot \mathrm{kg}^{-1}\right)$ & 557 \\
\hline Total $\mathrm{Cu}\left(\mathrm{mg} \cdot \mathrm{kg}^{-1}\right)$ & 5970 \\
\hline Total Zn (mg $\left.\cdot \mathrm{kg}^{-1}\right)$ & 27362 \\
\hline Total B (mg. kg ${ }^{-1}$ ) & 110 \\
\hline
\end{tabular}

Table 2. Chemical characteristics of the soils used in the study.

\begin{tabular}{|c|c|c|c|c|}
\hline \multirow{3}{*}{ Analyzed parameter } & \multicolumn{4}{|c|}{ Location and soil depth (cm) } \\
\hline & \multicolumn{2}{|c|}{ Chillán } & \multicolumn{2}{|c|}{ Talca } \\
\hline & $0-20$ & $20-40$ & $0-20$ & $20-40$ \\
\hline $\mathrm{pH}$ & 6.21 & 6.45 & 6.33 & 6.44 \\
\hline $\mathrm{EC}\left(\mathrm{dS} \cdot \mathrm{m}^{-1}\right)$ & 0.06 & 0.03 & 0.09 & 0.04 \\
\hline $\mathrm{OM}\left(\mathrm{g} \cdot \mathrm{kg}^{-1}\right)$ & 84.6 & 56.8 & 27.2 & 14.0 \\
\hline Available $\mathrm{N}\left(\mathrm{mg} \cdot \mathrm{kg}^{-1}\right)$ & 17.9 & 7.5 & 16.0 & 5.0 \\
\hline Available Olsen P $\left(\mathrm{mg} \cdot \mathrm{kg}^{-1}\right)$ & 15.3 & 10.9 & 72.0 & 14.0 \\
\hline K cation exchange $\left(\mathrm{cmol}_{(+)} \cdot \mathrm{kg}^{-1}\right)$ & 0.23 & 0.37 & 0.90 & 0.34 \\
\hline Ca cation exchange $\left(\mathrm{cmol}_{(+)} \cdot \mathrm{kg}^{-1}\right)$ & 5.28 & 4.23 & 8.64 & 9.85 \\
\hline Mg cation exchange $\left(\mathrm{cmol}_{(+)} \cdot \mathrm{kg}^{-1}\right)$ & 0.75 & 0.47 & 3.44 & 3.81 \\
\hline Na cation exchange $\left(\mathrm{cmol}_{(+)} \cdot \mathrm{kg}^{-1}\right)$ & 0.16 & 0.16 & 0.20 & 0.24 \\
\hline Available S (mg· kg ${ }^{-1}$ ) & 13.4 & 16.2 & 2.0 & 2.5 \\
\hline Available Fe (mg $\left.\cdot \mathrm{kg}^{-1}\right)$ & 53.0 & 36.2 & 133.0 & 99.0 \\
\hline Available Mn (mg· kg-1) & 8.6 & 4.7 & 31.0 & 24.0 \\
\hline Available Zn (mg· $\mathrm{kg}^{-1}$ ) & 0.26 & 0.09 & 6.0 & 0.6 \\
\hline Available $\mathrm{Cu}\left(\mathrm{mg} \cdot \mathrm{kg}^{-1}\right)$ & 1.40 & 0.46 & 4.9 & 2.9 \\
\hline Available B (mg $\left.\mathrm{kg}^{-1}\right)$ & 0.26 & 0.17 & 0.65 & 0.37 \\
\hline
\end{tabular}

EC: electric conductivity, OM: organic matter. 
in each plot, 20 and 10 contiguous plants from the central rows were collected; the whole plant was cut at $10 \mathrm{~cm}$ above the soil surface and weighed. Harvested weights were recorded as fresh yields and the moisture content was determined by oven drying at $70^{\circ} \mathrm{C}$ for $48 \mathrm{~h}$. Grains were harvested by stripping the corn cob and drying at $70^{\circ} \mathrm{C}$ for $96 \mathrm{~h}$; grain yield was then adjusted to $14.5 \%$ moisture.

\subsection{Data Collection and Analysis}

Grain yield (GY), dry matter (DM) and $\mathrm{Zn}$ and $\mathrm{Cu}$ concentrations were determined. Dried plant subsamples were ground with a mill, passed through a $2 \mathrm{~mm}$ sieve, and analyzed. The $\mathrm{Zn}$ and $\mathrm{Cu}$ concentrations were determined by sample calcinations and atomic absorption spectrometry. Extractable soil $\mathrm{Zn}$ and $\mathrm{Cu}$ analysis was performed on 10 subsamples from each experimental unit collected at harvest at two depths of 0 - 20 and 20 - 40 $\mathrm{cm}$. Samples were air dried, passed through a $2 \mathrm{~mm}$ sieve, and $\mathrm{Zn}$ and $\mathrm{Cu}$ analyzed by extraction with diethylenetriamine-pentaacetic acid (DTPA) in a 1:2 ratio; the elements in solution were determined by flame atomic absorption spectrometry. In addition, $\mathrm{pH}$ was determined by directly measuring the 1:2.5 aqueous extract (Potentiometer) given its relationship with $\mathrm{Zn}$ and $\mathrm{Cu}$ availability [22].

\subsection{Statistical Analysis}

Results were examined by ANOVA and Tukey's multiple range test $(p=0.05)$ were used for the comparation of means with the SAS general model procedure [23]. When data were not normally distributed [24], the diagnostic procedure was used to select the most appropriate transformation. Treatments and the locations were considered as fixed effects and the replicates as random effects.

\section{Results}

\subsection{Chemical Soil Properties}

The chemical properties in the two locations differed (Table 2) and only Talca exhibited an overall adequate fertility level for all the essential elements, except sulfur (S); this was pointed out by [25]. On the other hand, the initial levels of $\mathrm{Zn}$ and $\mathrm{Cu}$ found in Talca were not considered excessive for corn crop [22] [25]. High corn yields have also been reported in previous experiments for both locations [11] [26]. As soil pH affects $\mathrm{Zn}$ and $\mathrm{Cu}$ availability, the values obtained in the present study for this parameter in both locations might did not affect their availability (Table 2) [22].

\subsection{Whole Plant Dry Matter Production and Zinc and Copper Concentrations}

Dry matter production was significantly different in the two locations $(\mathrm{p}<0.01)$; it was also affected by the fertilization treatment $(p<0.01)$ and by the interaction between both sources of variation $(p<0.05)$ (Table 3$)$. Whole plant $\mathrm{Zn}$ concentration was only affected by location ( $\mathrm{p}<0.01)$, whereas $\mathrm{Cu}$ concentration was affected by the type of fertilization $(\mathrm{p}<0.01)$ and the location-fertilization treatment interaction $(\mathrm{p}<0.01)$ (Table 3$)$. High DM production in Chillán was obtained with CF (350 kg N ha $\left.{ }^{-1}\right)$ and PC2 (700 kg N ha $\left.{ }^{-1}\right)$ and PC3 (1400 $\left.\mathrm{kg} \mathrm{N} \mathrm{ha}^{-1}\right)(\mathrm{p}<0.05)$, which were higher than C (Figure 1).

Corn plant $\mathrm{Zn}$ concentration in response to fertilization treatments differed only in Talca (Figure 2); the highest concentration was obtained in the control, which surpassed CF and PC3 (1400 kg N ha $\left.{ }^{-1}\right)(\mathrm{p}<0.05)$, while PC1 and PC2 did not present significant differences compared to C. The Zn concentration fluctuated between 42.0 and $76.1 \mathrm{mg} \cdot \mathrm{kg}^{-1}$ in Chillán and between 13.5 and $21.2 \mathrm{mg} \cdot \mathrm{kg}^{-1}$ in Talca; these values were in the normal range mentioned by [27] for corn leaves.

Similar to corn plant $\mathrm{Zn}$ concentration, $\mathrm{Cu}$ concentration was different only in Talca (Figure 3), and the highest concentration was obtained in CF, and the lowest in PC3. The Cu content was significantly higher $(\mathrm{p}<$ 0.05) in CF than in any other treatments.

\subsection{Grain Yield and Grain Zinc and Copper Concentrations}

Grain yield was significantly different between locations $(\mathrm{p}<0.05)$ and affected by the fertilization treatments $(p<0.01)$; there was no observed interaction between both factors $(p>0.05)$ (Table 3). Grain Zn concentration was not affected by any of the sources of variation ( $p>0.05$ ), whereas $\mathrm{Cu}$ concentration was affected by both 
Table 3. Significance of statistical analysis of parameters evaluated in the experiment.

\begin{tabular}{|c|c|c|c|}
\hline \multirow{2}{*}{ Evaluated parameter } & \multicolumn{3}{|c|}{ Sources of variation } \\
\hline & Location (L) & Fertilization treatment $(\mathrm{F})$ & Interaction $(\mathrm{L} \times \mathrm{F})$ \\
\hline DM production & $* *$ & ** & $*$ \\
\hline DM Zn concentration & ** & ns & ns \\
\hline DM Cu concentration & ns & ** & ** \\
\hline Grain yield & * & ** & ns \\
\hline Grain Zn concentration & ns & ns & ns \\
\hline Grain $\mathrm{Cu}$ concentration & ** & $* *$ & ns \\
\hline Soil pH $0-20 \mathrm{~cm}$ & ** & $* *$ & * \\
\hline Soil pH 20 - 40 cm & ** & ns & ns \\
\hline Soil Zn 0 - 20 cm & ns & ** & ns \\
\hline Soil Zn $20-40 \mathrm{~cm}$ & * & ** & ns \\
\hline Soil Cu 0 - $20 \mathrm{~cm}$ & ** & ** & ns \\
\hline Soil Cu 20 - 40 cm & $* *$ & ** & $*$ \\
\hline
\end{tabular}

${ }^{* *}$ Significance $<0.01$. ${ }^{*}$ Significance between 0.01 and $0.05 .{ }^{\text {ns }}$ Non significant. DM: dry matter.

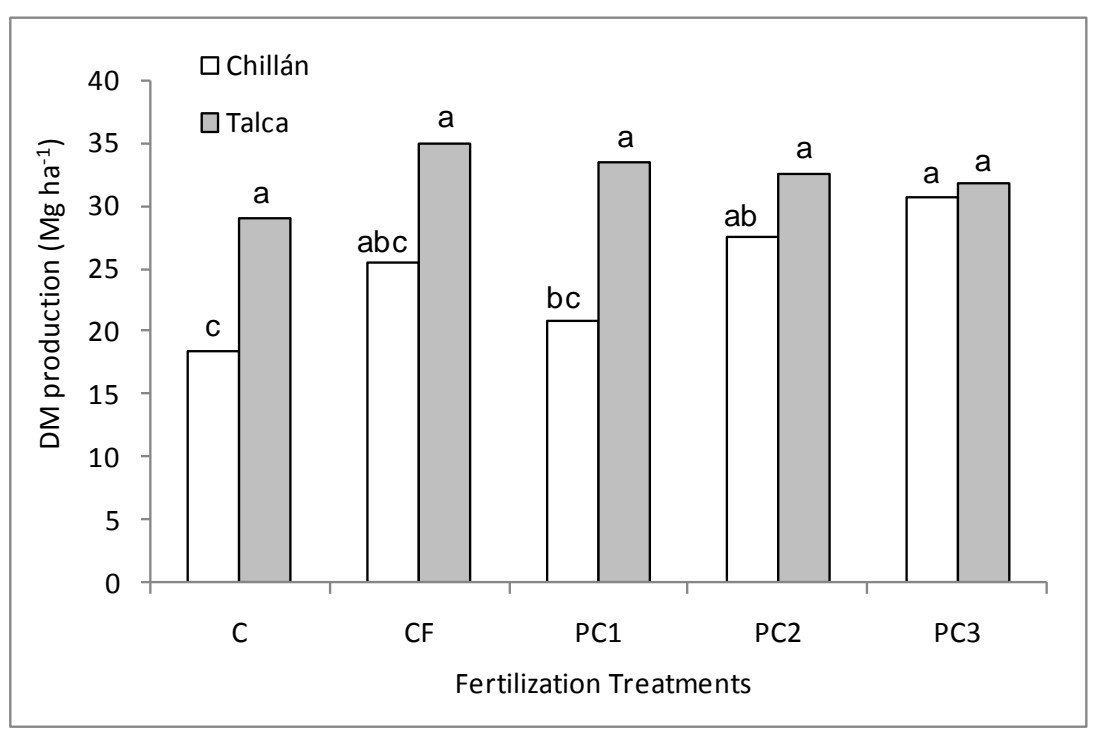

Figure 1. Total whole plant DM production at corn grain harvest in both locations. Different letters over the columns for the same location indicate a statistical difference among fertilization treatments according to Tukey's test ( $<<0.05)$. C: control without fertilization; CF: conventional fertilization at $350 \mathrm{~kg} \mathrm{~N}^{-1}$ rate; PC1: pig compost at $350 \mathrm{~kg} \mathrm{~N} \mathrm{ha}^{-1}$ rate $\left(15.33 \mathrm{Mg} \mathrm{PC} \mathrm{ha}^{-1}\right)$; PC2: pig compost at $700 \mathrm{~kg} \mathrm{~N}^{-1}$ rate (30.65 Mg PC ha ${ }^{-1}$ ); PC3: pig compost at $1400 \mathrm{~kg} \mathrm{~N}^{-1}$ rate (61.31 $\mathrm{Mg} \mathrm{PC} \mathrm{ha}^{-1}$ ).

location and type of fertilization $(\mathrm{p}<0.01)$ and there was no location-fertilization treatment interaction $(\mathrm{p}>0.05)$ (Table 3). The highest GY in Chillán was obtained with PC3 (1400 kg N ha ${ }^{-1}$ ), which was significantly different to $\mathrm{C}$ and PC1 (350 $\left.\mathrm{kg} \mathrm{N} \mathrm{ha}^{-1}\right)(\mathrm{p}<0.05)$ and did not presented differences among CF and PC2 (Figure 4). There was no difference in GY among the fertilized treatments in Talca ( $p>0.05$ ), whereas only CF surpassed C ( $<$ 0.05) (Figure 4), this is likely attributable to the adequate soil chemical properties (Table 2).

Grain Zn concentration fluctuated between 23.7 and $42.2 \mathrm{mg} \cdot \mathrm{kg}^{-1}$ in Chillán and between 26.2 and 33.8 


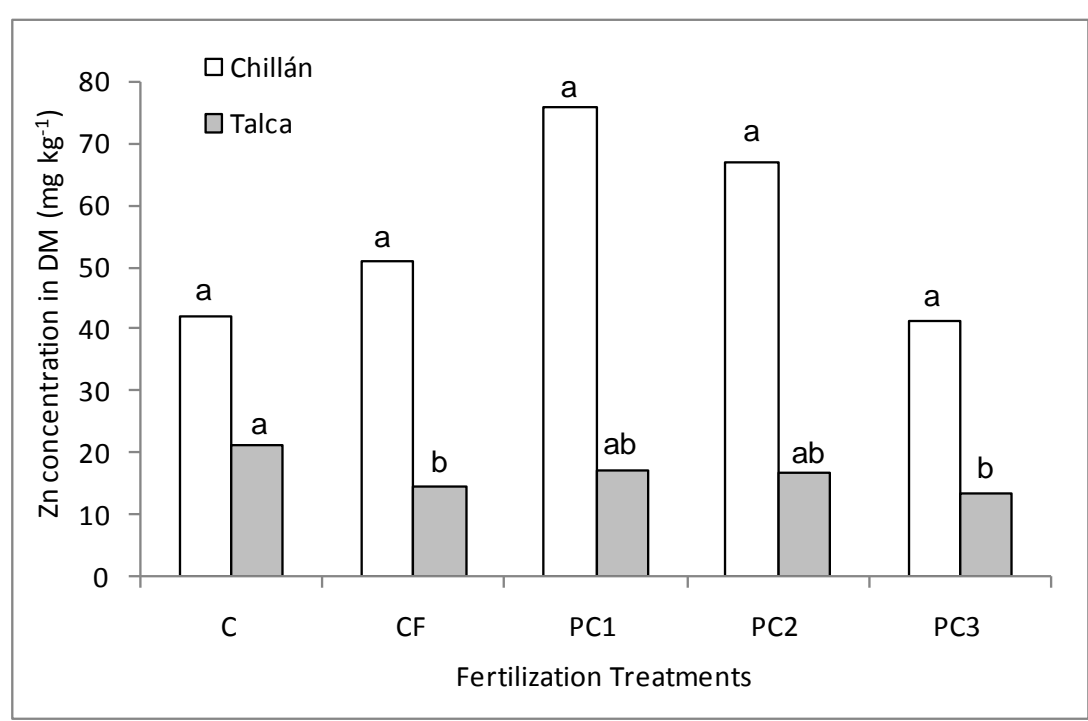

Figure 2. Whole plant Zn concentration at corn grain harvest in both locations. Different letters over the columns for the same location indicate a statistical difference among fertilization treatments according to Tukey's test $(\mathrm{p}<0.05)$. C: control without fertilization; CF: conventional fertilization at $350 \mathrm{~kg} \mathrm{~N}^{-1}$ rate; PC1: pig compost at $350 \mathrm{~kg} \mathrm{~N} \mathrm{ha}^{-1}$ rate $\left(15.33 \mathrm{Mg} \mathrm{PC} \mathrm{ha}^{-1}\right.$ ); PC2: pig compost at $700 \mathrm{~kg} \mathrm{~N}^{-1}$ rate (30.65 Mg PC ha'); PC3: pig compost at $1400 \mathrm{~kg} \mathrm{~N}^{-1} \mathrm{M}^{-1}$ rate (61.31 Mg PC ha-1).

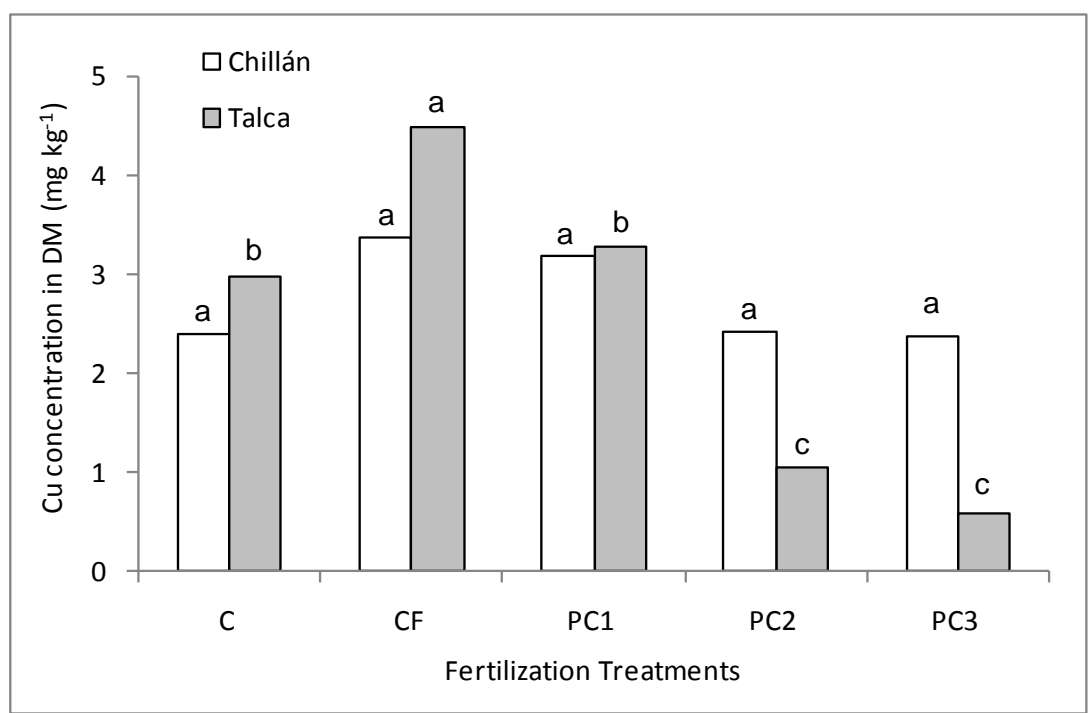

Figure 3. Whole plant $\mathrm{Cu}$ concentration at corn grain harvest in both locations. Different letters over the columns for the same location indicate a statistical difference among fertilization treatments according to Tukey's test $(\mathrm{p}<0.05)$. C: control without fertilization; CF: conventional fertilization at $350 \mathrm{~kg} \mathrm{~N}^{-1}$ rate; $\mathrm{PC1}$ : pig compost at $350 \mathrm{~kg} \mathrm{~N} \mathrm{ha}^{-1}$ rate $\left(15.33 \mathrm{Mg} \mathrm{PC} \mathrm{ha}^{-1}\right)$; PC2: pig compost at $700 \mathrm{~kg} \mathrm{~N}^{-1}$ rate (30.65 Mg PC ha'); PC3: pig compost at $1400 \mathrm{~kg} \mathrm{~N} \mathrm{ha}^{-1}$ rate (61.31 $\mathrm{Mg} \mathrm{PC} \mathrm{ha}^{-1}$ ).

$\mathrm{mg} \cdot \mathrm{kg}^{-1}$ in Talca (Figure 5). Although there were no significant differences in these concentrations (Table 3), an erratic effect was observed in quantitative terms in the evaluated fertilization treatments (Figure 5).

Corn grain $\mathrm{Cu}$ concentration fluctuated between 1.8 and $2.4 \mathrm{mg} \cdot \mathrm{kg}^{-1}$ in Chillán and between 2.2 and 2.8 $\mathrm{mg} \cdot \mathrm{kg}^{-1}$ in Talca (Figure 6) and exhibited differences in fertilization treatments only in Talca where the highest content was obtained in PC3 treatment $\left(1400 \mathrm{~kg} \cdot \mathrm{ha}^{-1}\right)$. Only significantly difference was found between this treatment and the $\mathrm{C}$ while no differences were obtained among the fertilizer treatments. 


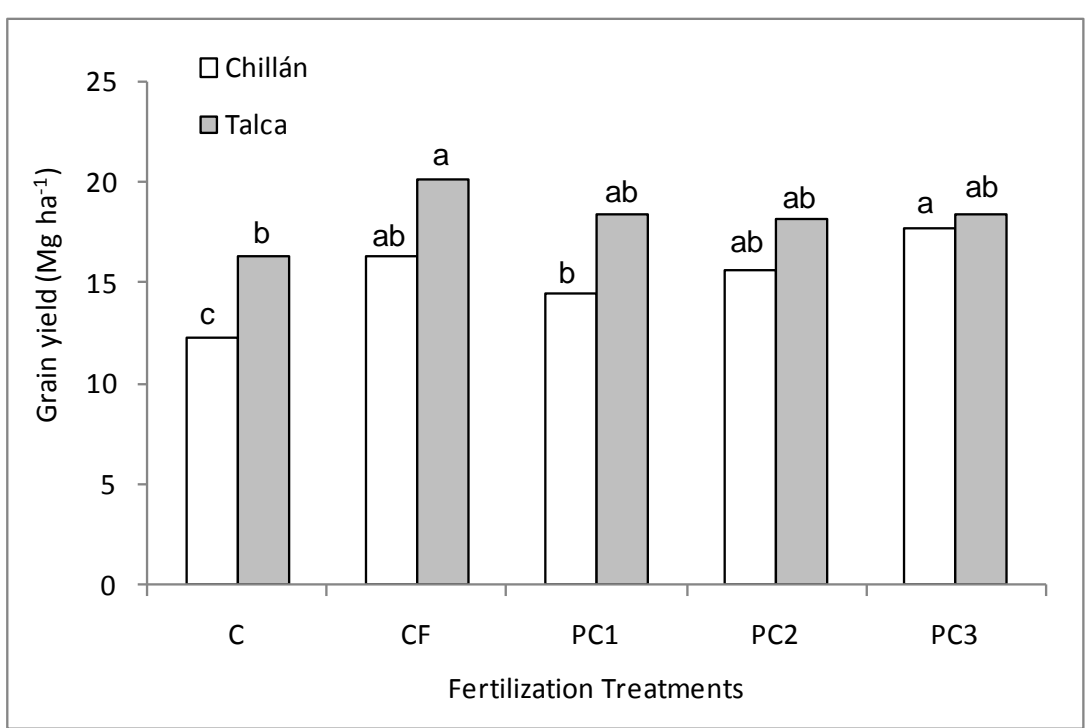

Figure 4. Corn grain yield in both locations. Different letters over the columns for the same location indicate a statistical difference among fertilization treatments according to Tukey's test $(\mathrm{p}<0.05)$. C: control without fertilization; CF: conventional fertilization at $350 \mathrm{~kg} \mathrm{~N}^{-1}$ rate; PC1: pig compost at $350 \mathrm{~kg} \mathrm{~N}^{-1}$ rate (15.33 Mg PC ha ${ }^{-1}$ ); PC2: pig compost at $700 \mathrm{~kg} \mathrm{~N}^{-1}$ rate (30.65 $\mathrm{Mg} \mathrm{PC} \mathrm{ha-1);} \mathrm{PC3:} \mathrm{pig}$ compost at $1400 \mathrm{~kg} \mathrm{~N}^{-1}$ rate (61.31 $\left.\mathrm{Mg} \mathrm{PC} \mathrm{ha}^{-1}\right)$.

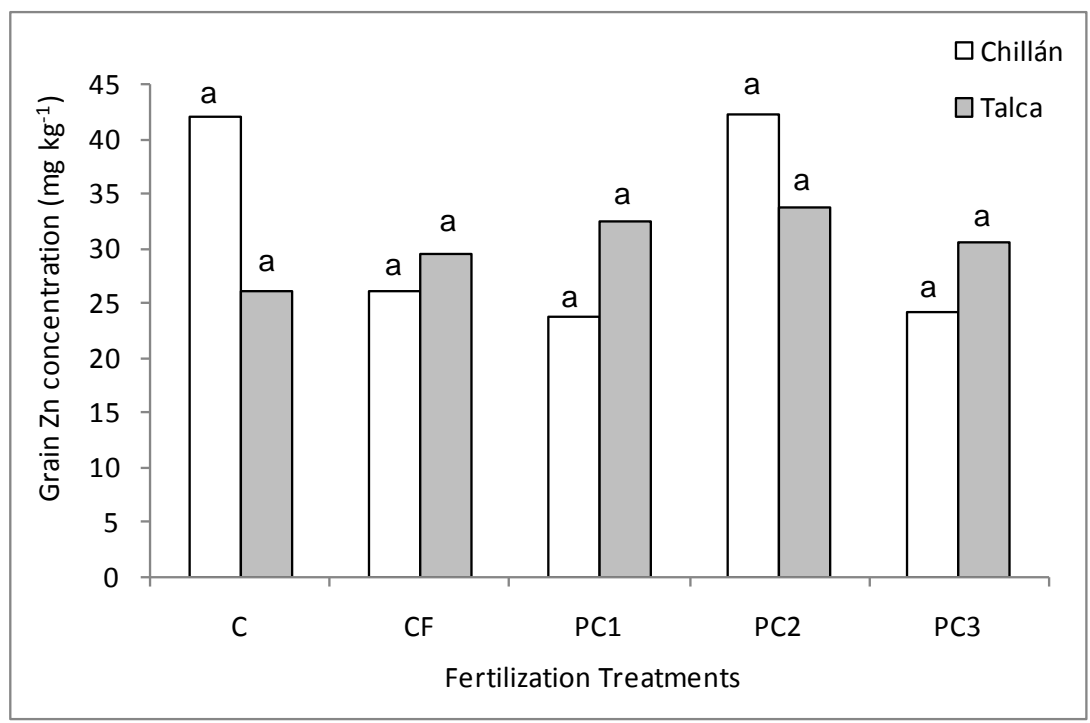

Figure 5. Total corn grain Zn concentration in both locations. Different letters over the columns for the same location indicate a statistical difference among fertilization treatments according to Tukey's test $(\mathrm{p}<0.05)$. C: control without fertilization; CF: conventional fertilization at $350 \mathrm{~kg} \mathrm{~N}^{-1}$ rate; PC1: pig compost at $350 \mathrm{~kg} \mathrm{~N}^{-1}$ rate $\left(15.33 \mathrm{Mg} \mathrm{PC} \mathrm{ha}^{-1}\right)$; PC2: pig compost at $700 \mathrm{~kg} \mathrm{~N}^{-1}$ rate $\left(30.65 \mathrm{Mg} \mathrm{PC} \mathrm{ha}^{-1}\right)$; PC3: pig compost at $1400 \mathrm{~kg} \mathrm{~N}^{-1}$ rate $\left(61.31 \mathrm{Mg} \mathrm{PC} \mathrm{ha}^{-1}\right)$.

\subsection{Effects on $\mathrm{pH}$ and Soil $\mathrm{Zn}$ and $\mathrm{Cu}$ Concentrations}

Soil $\mathrm{pH}$ from 0 to $20 \mathrm{~cm}$ depth was significantly affected by location $(\mathrm{p}<0.01)$, fertilization treatments $(\mathrm{p}<$ 0.01 ), and by the interaction between both variables $(\mathrm{p}<0.05)$ (Table 3). Significant difference attributable to location was found only in the 20 to $40 \mathrm{~cm}$ soil stratum ( $<0.01$ ) (Table 3). This soil chemical property was determined because changes in this parameter can affect soil Zn and Cu availability [22]. Chillán location exhibited 
a slight high $\mathrm{pH}$ mean in the second soil stratum; however, no significant differences were seen among treatments (Table 4). The highest $\mathrm{pH}$ in the first soil layer was found in PC3 treatment (1400 kg N ha ${ }^{-1}$ ), which was only significantly different with the CF treatment (Table 4). Soil pH in Talca was slight higher than Chillán for both soil depths (Table 3 and Table 4). Just as in Chillán, when comparing mean $\mathrm{pH}$ in both depths the highest value was found at $20-40 \mathrm{~cm}$ (Table 4). The differences detected in the first soil layer in Talca indicated that the highest $\mathrm{pH}$ was obtained in C, which present significantly differences with CF and PC3 (1400 kg N ha $\left.{ }^{-1}\right)$. On the other hand, similar results were obtained for Chillán, where the highest acidification was obtained with CF which was significantly different only with PC3 treatment.

Extractable soil Zn concentration in the surface soil layer $(0-20 \mathrm{~cm})$ showed only differences among fertilization treatments $(\mathrm{p}<0.01)$ (Table 3$)$; differences in the subsurface layer $(20-40 \mathrm{~cm})$ were found in both source of variation, location $(\mathrm{p}<0.05)$ and fertilization treatments $(\mathrm{p}<0.01)$ and there was no interaction between

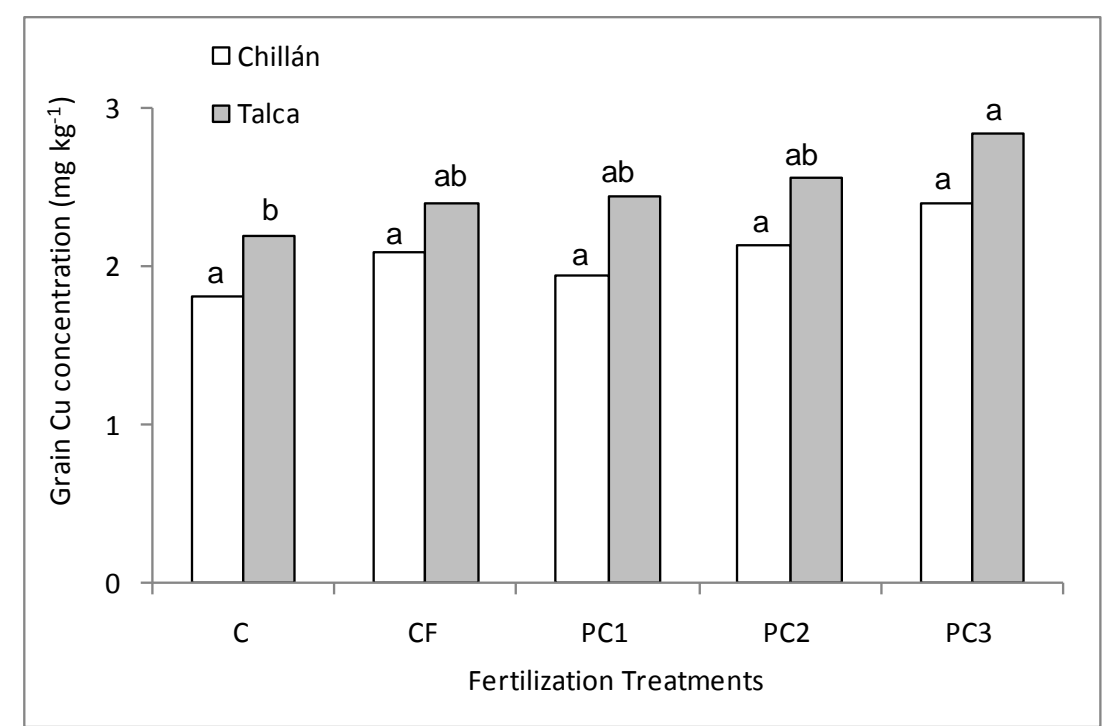

Figure 6. Total corn grain $\mathrm{Cu}$ concentration in both locations. Different letters over the columns for the same location indicate a statistical difference among fertilization treatments according to Tukey's test $(\mathrm{p}<0.05)$. C: control without fertilization; CF:

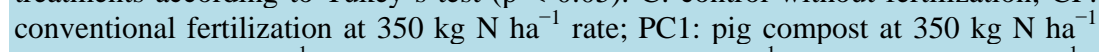
rate (15.33 $\mathrm{Mg} \mathrm{PC} \mathrm{ha}^{-1}$ ); PC2: pig compost at $700 \mathrm{~kg} \mathrm{~N}^{-1}$ rate (30.65 $\mathrm{Mg} \mathrm{PC} \mathrm{ha}^{-1}$ ); PC3: pig compost at $1400 \mathrm{~kg} \mathrm{~N}^{-1}$ rate $\left(61.31 \mathrm{Mg} \mathrm{PC} \mathrm{ha}^{-1}\right)$.

Table 4. Soil pH at corn harvest in both locations.

\begin{tabular}{ccccc}
\hline & \multicolumn{4}{c}{ Location and soil depth (cm) } \\
\cline { 2 - 5 } Treatment & \multicolumn{3}{c}{ Chillán } \\
\cline { 2 - 5 } & $0-20$ & $20-40$ & $0-20$ & $20-40$ \\
\hline C & $6.21 \mathrm{ab}$ & $6.29 \mathrm{a}$ & $6.62 \mathrm{a}$ & $6.88 \mathrm{a}$ \\
CF & $5.93 \mathrm{~b}$ & $6.20 \mathrm{a}$ & $6.12 \mathrm{c}$ & $6.81 \mathrm{a}$ \\
PC1 & $6.08 \mathrm{ab}$ & $6.23 \mathrm{a}$ & $6.48 \mathrm{ab}$ & $6.77 \mathrm{a}$ \\
PC2 & $6.13 \mathrm{ab}$ & $6.29 \mathrm{a}$ & $6.41 \mathrm{ab}$ & $6.74 \mathrm{a}$ \\
PC3 & $6.29 \mathrm{a}$ & $6.33 \mathrm{a}$ & $6.26 \mathrm{bc}$ & $6.69 \mathrm{a}$ \\
CV (\%) & 2.45 & 1.39 & 2.01 & 1.02 \\
\hline
\end{tabular}

Different letters in the same column indicate statistical difference according to Tukey's test $(\mathrm{p}<0.05)$; C: control without fertilization; CF: conventional fertilization at $350 \mathrm{~kg} \mathrm{~N}^{-1}$ rate; PC1: pig compost at $350 \mathrm{~kg} \mathrm{~N} \mathrm{ha}^{-1}$ rate $\left(15.33 \mathrm{Mg} \mathrm{PC} \mathrm{ha}^{-1}\right)$; PC2: pig compost at $700 \mathrm{~kg} \mathrm{~N} \mathrm{ha}^{-1}$ rate (30.65 $\mathrm{Mg} \mathrm{PC} \mathrm{ha}^{-1}$ ); PC3: pig compost at $1400 \mathrm{~kg} \mathrm{~N}^{-1}$ rate (61.31 $\left.\mathrm{Mg} \mathrm{PC} \mathrm{ha}^{-1}\right)$; CV: coefficient of variation. 
them (Table 3). Except for PC3 treatment the organic amendment applied did not produce any differences respect to the control in both soils (Table 5). For the first soil layer, PC application led to a slight, non-significant increase in extractable soil Zn contents in Talca location. Non-significantly differences were found among all treatments, this fact may be explained by the high coefficient of variation obtained (Table 5). The highest Zn concentration in the second soil stratum was observed with PC3 $\left(1400 \mathrm{~kg} \mathrm{~N} \mathrm{ha}^{-1}\right)$, which surpassed only C and CF treatments $(\mathrm{p}<0.01)$ and no differences between these former treatments was found (Table 5).

Extractable soil $\mathrm{Cu}$ concentration in the upper soil layer showed differences between locations $(\mathrm{p}<0.001)$ and treatments $(\mathrm{p}<0.01)$ and no interaction between these sources of variation was seen (Table 3$)$. While for the second soil layer the extractable soil $\mathrm{Cu}$ was affected by both sources of variation (Table 3). Extractable soil $\mathrm{Cu}$ contents located in Chillán exhibited the same effect in both depths where the highest concentration was found at PC3 treatment (1400 $\mathrm{kg} \mathrm{N} \mathrm{ha}^{-1}$ ), which it value was significantly different to $\mathrm{C}$ and $\mathrm{CF}$, while no differences were found among PC treatments (Table 6). As for soil Zn concentration, the high coefficient of variation for this nutrient in both stratums is emphasized (Table 6). There were no significant differences in extractable soil $\mathrm{Cu}$ contents location in Talca at any of the soil depths (Table 6).

\section{Discussion}

A positive DM production response was observed with the increasing PC rates (Figure 1), which indicates that

Table 5. Soil Zn concentration at time to corn harvest in both locations.

\begin{tabular}{|c|c|c|c|c|}
\hline \multirow{3}{*}{ Treatment } & \multicolumn{4}{|c|}{ Location and soil depth (cm) } \\
\hline & \multicolumn{2}{|c|}{ Chillán } & \multicolumn{2}{|c|}{ Talca } \\
\hline & $0-20$ & $20-40$ & $0-20$ & $20-40$ \\
\hline $\mathrm{C}$ & $0.26 \mathrm{~b}$ & $0.29 \mathrm{~b}$ & $1.72 \mathrm{a}$ & $0.66 \mathrm{~b}$ \\
\hline $\mathrm{CF}$ & $0.25 \mathrm{~b}$ & $0.22 \mathrm{~b}$ & $2.75 \mathrm{a}$ & $0.67 \mathrm{~b}$ \\
\hline PC1 & $3.61 \mathrm{ab}$ & $2.25 \mathrm{ab}$ & $9.72 \mathrm{a}$ & $2.08 \mathrm{ab}$ \\
\hline PC2 & $10.55 \mathrm{ab}$ & $6.46 \mathrm{ab}$ & $15.4 \mathrm{a}$ & $2.03 \mathrm{ab}$ \\
\hline PC3 & 16.18 a & $8.20 \mathrm{a}$ & $15.62 \mathrm{a}$ & 3.99 a \\
\hline CV (\%) & 104.3 & 84.9 & 85.3 & 68.2 \\
\hline
\end{tabular}

Different letters in the same column indicate a statistical difference according to Tukey’s test (p < 0.05); C: control without fertilization; CF: conventional fertilization at $350 \mathrm{~kg} \mathrm{~N}^{-1}$ rate; PC1: pig compost at $350 \mathrm{~kg} \mathrm{~N} \mathrm{ha}^{-1}$ rate $\left(15.33 \mathrm{Mg} \mathrm{PC} \mathrm{ha}^{-1}\right.$ ); PC2: pig compost at $700 \mathrm{~kg} \mathrm{~N}^{-1}$ rate (30.65 $\mathrm{Mg}$ PC ha ${ }^{-1}$ ); PC3: pig compost at $1400 \mathrm{~kg} \mathrm{~N}^{-1}$ rate (61.31 $\mathrm{Mg} \mathrm{PC} \mathrm{ha}^{-1}$ ) CV: coefficient of variation.

Table 6. Soil Cu concentration at time to corn harvest in both locations.

\begin{tabular}{|c|c|c|c|c|}
\hline \multirow{3}{*}{ Treatment } & \multicolumn{4}{|c|}{ Location and soil depth (cm) } \\
\hline & \multicolumn{2}{|c|}{ Chillán } & \multicolumn{2}{|c|}{ Talca } \\
\hline & $0-20$ & $20-40$ & $0-20$ & $20-40$ \\
\hline $\mathrm{C}$ & $1.40 \mathrm{~b}$ & $1.31 \mathrm{~b}$ & $3.11 \mathrm{a}$ & $2.94 \mathrm{a}$ \\
\hline $\mathrm{CF}$ & $1.41 \mathrm{~b}$ & $1.10 \mathrm{~b}$ & $3.70 \mathrm{a}$ & $2.92 \mathrm{a}$ \\
\hline PC1 & $2.12 \mathrm{ab}$ & $1.72 \mathrm{ab}$ & $5.02 \mathrm{a}$ & $3.43 \mathrm{a}$ \\
\hline PC2 & $3.40 \mathrm{ab}$ & $2.43 \mathrm{ab}$ & $5.91 \mathrm{a}$ & $3.12 \mathrm{a}$ \\
\hline PC3 & $4.40 \mathrm{a}$ & $2.92 \mathrm{a}$ & $5.87 \mathrm{a}$ & $3.31 \mathrm{a}$ \\
\hline CV (\%) & 44.3 & 32.7 & 35.4 & 10.7 \\
\hline
\end{tabular}

Different letters in the same column indicate a statistical difference according to Tukey's test ( $<<0.05)$; C: control without fertilization; CF: conventional fertilization at $350 \mathrm{~kg} \mathrm{~N} \mathrm{ha}^{-1}$ rate; PC1: pig compost at $350 \mathrm{~kg} \mathrm{~N} \mathrm{ha}^{-1}$ rate $\left(15.33 \mathrm{Mg} \mathrm{PC} \mathrm{ha}^{-1}\right.$ ); PC2: pig compost at $700 \mathrm{~kg} \mathrm{~N}^{-1}$ rate (30.65 $\mathrm{Mg}$ PC ha ${ }^{-1}$ ); PC3: pig compost at $1400 \mathrm{~kg} \mathrm{~N} \mathrm{ha}^{-1}$ rate (61.31 Mg PC ha' ${ }^{-1}$ ) CV: coefficient of variation. 
there was no negative effect of using PC in corn for the evaluated rates, associate to its slow $\mathrm{N}$ mineralization [2] [6] [10]. Dry matter production in the fertilized treatments fluctuated between 20.9 and $30.6 \mathrm{Mg} \cdot \mathrm{ha}^{-1}$; these values were similar to those mentioned by [8] for silage corn in the same production area. No difference in DM production was observed in Talca (Figure 1) for the evaluated treatments ( $>0.05$ ); this is attributable to soil chemical properties (Table 2). Dry matter production obtained in the fertilized treatments fluctuated between 31.8 and $35.0 \mathrm{Mg} \cdot \mathrm{ha}^{-1}$, which was similar to values indicated by [26].

Corn plant Zn concentration values obtained in Chillán were higher than those found by [28] for different corn plant tissues amended with sewage sludge compost; while the values obtained in Talca were lower than those found by those authors. The quantitative differences between both locations is likely due to the initial chemical properties of each soil (Table 2) since the availability of each nutrient is affected by the concentration of other nutrients, such as phosphorus and calcium, and the presence of secondary crystalline minerals found in higher proportions in Talca [22]. In general, an inversely proportional relationship was observed between corn plant Zn concentration and increasing PC rates in both locations (Figure 2). In contrast, [18] indicate significant increases in Zn concentration in ryegrass (Lolium multiflorum Lam.) stems and roots amended with sewage sludge at a rate of $140 \mathrm{Mg} \cdot \mathrm{ha}^{-1}$ (730.5 $\mathrm{mg} \cdot \mathrm{Zn} \cdot \mathrm{kg}^{-1}$ ) as compared to C and CF with NPK contributions equivalent to using organic amendment.

For the corn plant $\mathrm{Cu}$ concentration in quantitative terms, an inversely proportional effect was observed for both locations with the increasing PC rates (Figure 3), associate to the reactions with the organic compounds applied [22]. Copper concentration fluctuated between 2.0 and $3.4 \mathrm{mg} \cdot \mathrm{kg}^{-1}$ in Chillán and between 0.6 and 4.5 $\mathrm{mg} \cdot \mathrm{kg}^{-1}$ in Talca; these were below the normal range mentioned by [27] for corn leaves and similar to values pointed out by [28] for different corn plant tissues amended with sewage sludge compost. [18] experimented with ryegrass amended with sewage sludge at a rate of $140 \mathrm{Mg} \cdot \mathrm{ha}^{-1}\left(204.5 \mathrm{mg} \cdot \mathrm{Zn} \cdot \mathrm{kg}^{-1}\right)$ and indicated that applying this organic amendment produced significant increases in $\mathrm{Cu}$ concentration in ryegrass stems and roots as compared to $\mathrm{C}$ and $\mathrm{CF}$.

The same as in DM production, a positive response in GY was observed with increasing PC rates (Figure 4); there was no negative effect of using PC in corn crop for the evaluated rates, associate to slow availability of the total $\mathrm{N}$ applied and the chemicals reactions between organic compounds and the nutrients applied with the PC [29]. In Chillán GY in the treatments applied fluctuated between 14.4 and $17.7 \mathrm{Mg} \cdot \mathrm{ha}^{-1}$, which is similar to values mentioned by [30] in central Chile and slightly lower than those found by [26] in south central Chile.

For Talca the GY in the fertilized treatments fluctuated between 18.2 and $20.1 \mathrm{Mg} \cdot \mathrm{ha}^{-1}$; these values were similar to those indicated by [26] and higher than those found by [30].

Grain Zn concentration values (Figure 5) were generally similar to those pointed out by [28] for corn amended with sewage sludge compost. Unlike the difference obtained in whole plant Zn concentration, there were no quantitative differences in grain concentration between locations; the mean value in the treatments with PC were 30.0 and $32.3 \mathrm{mg} \cdot \mathrm{kg}^{-1}$ in Chillán and Talca, respectively.

The mean grain $\mathrm{Cu}$ concentration was higher in Talca than Chillán (Figure 6); this fact may be was attributable to the different chemical properties of both soils (Table 2). Grain Cu concentrations in both locations were similar to those mentioned by [28] for corn amended with sewage sludge compost.

Respect to the soil in both locations, the lower $\mathrm{pH}$ obtained with the conventional fertilization (urea) use, which is in agreement from this reported by [2] who indicated that the application of conventional fertilizer (urea) produced soil acidification. The acidification generated with the PC use in high rate for the first stratum in Talca is related to the use of composted organic amendments and its carbon mineralization and release of organic acids, as has also been reported by several authors [2] [11] [13] [29] [31] and too can be attributed to the nitrification of ammonia-N [22] [29].

Although a difference in $\mathrm{pH}$ existed at the start of the experiment (Table 2 and Table 4), this difference increased in Talca. This is due to the higher level of clay content and its structural characteristics (crystalline clay type 1:1 and 2:1 soils in Talca compared to the amorphous clay soils in Chillán), which produced base accumulation by illuviation in the second soil stratum [22].

Soil Zn concentration in Chillán showed the same effect in both soil depths and the highest concentration was obtained with PC3 $\left(1400 \mathrm{~kg} \mathrm{~N} \mathrm{ha}^{-1}\right)$, which was only significantly different under C and CF treatments and no significant differences were seen among PC treatments (Table 5). The high variation coefficient found for this nutrient in both soil layers suggests, that long-term studies are needed in order to detect soil Zn concentration changes, such as the one carried out by [17] where organic amendments were applied to evaluate the over time, 
changes in soil heavy metal contents. The highest Zn concentration was found in the first stratum when comparing both soil layers, which was associated with the strong bonding of this nutrient to the organic matter, plus the higher $\mathrm{pH}$ in the subsurface soil layer [22]. Similar effects associated with applying increasing rates of sewage sludge compost were reported by [28]. Almost the same Chillán soil, the Zn concentration in Talca soil for first soil stratum are agree with the results obtained by [28]. The mean value of PC treatments for the first soil layer showed a higher Zn content in Talca soil than in Chillan soil, while the higher content in the second soil stratum was found in Chillán than in Talca soil (Table 5). The highest mean value of extractable soil Zn was found in Talca (Table 5), which agrees with the initial concentration of this nutrient in this soil (Table 2). The highest increase in Zn concentration in both soils was obtained in Chillán (Table 2 and Table 5); this is attributable to the type of clay, as well as lower soil pH [22]. The pH effect, which showed differences only between PC3 and $\mathrm{C}$ in the first soil layer could have contributed in increasing Zn concentration in this stratum [22] (Table 4 and Table 5). No toxicity reports exist for $\mathrm{Zn}$ in agricultural crops in Chile; this slight increase in concentration associated with PC at rates that meet crop nutritional needs does not constitute a risk as this alternative fertilization source.

The highest soil Cu concentration in Chillán was generally obtained in the first stratum (Table 6) associated with the low movement of this nutrient in the soil [22]. The results obtained agree with those registered by [28] in an increasing rates of sewage sludge compost study as well as differences in concentration between soil depths. As well as in Talca soil there were not differences between treatments for the soil Cu concentration, this lack of response may be due to the high coefficient of variation obtained in both soil strata (Table 6). Similarly to Chillán, a higher $\mathrm{Cu}$ concentration was found in the first soil stratum, but extractable soil $\mathrm{Cu}$ concentration in both stratums was higher in Talca (Table 6). However, considering the average applied treatments, the extractable soil $\mathrm{Cu}$ content regarding to the initial value, increased only in the Chillán soil (Table 2 and Table 6). This fact was attributable to the lower initial concentration and type of clay as well as lower soil pH [22]. The lack of differences among treatments and the slight increase in the extractable $\mathrm{Cu}$ concentration with regard to the initial value is an advantage for this organic amendment which has high $\mathrm{Cu}$ concentration. Soils high in crystalline clays, such as Talca soil are associated with the lack of response to $\mathrm{Cu}$ and $\mathrm{Zn}$ applied with the PC treatments. In addition, the soil $\mathrm{pH}$ in Talca did not affected the Cu availability, since only PC3 produced a lower pH than C in the first soil layer (Table 4), therefore the extractable soil $\mathrm{Cu}$ contents in this location and depths did not show significantly differences among treatments (Table 6). This effect is associated to chemicals reactions with the organic compounds presents in PC [29].

\section{Conclusion}

The results obtained indicated that the composted pig manure applied did not negatively affect corn crop cultivated in two soils with different pedological characteristics. In both soils, applying PC at rates adjusted to the N nutritional needs for corn production, showed a slightly, non-significant decrease of GY production without effect on grain $\mathrm{Zn}$ and $\mathrm{Cu}$ contents with respect to the conventional fertilization. At the same time, the DM production and Zn concentration in plant were not affected with this PC rate with respect to the conventional fertilization, but the $\mathrm{Cu}$ concentration in plant was decreased significantly in one of the two locations. An increase with increasing application rate in extractable soil $\mathrm{Zn}$ and $\mathrm{Cu}$ contents was observed in both soils, where the greater impact was obtained on the superficial soil stratum. However, both elements remained far below levels considered phytotoxic. Nevertheless, further medium and long-term monitoring should be undertaken in order to evaluate the possible changes in soil of these trace elements.

\section{Acknowledgements}

The author is thankful to the Servicios Pucalán Sur Company for co-financing this experiment and to the SEMAMERIS Company for facilitating their installations in their Talca experimental station.

\section{References}

[1] INN (2005) Norma Chilena de calidad de compost. NCh 2880. of 2005. Instituto Nacional de Normalización, Santiago.

[2] Hirzel, J. and Salazar, F. (2011) Uso de Enmiendas Orgánicas como Fuente de Fertilización en Cultivos. Fertilización de Cultivos en Chile. In: Hirzel, J., Ed., Colección Libros INIA No. 28, Chillán. 
[3] Hirzel, J., Cerda, F., Millas, P. and France, A. (2012) Compost Tea Effects on Production and Extraction of Nitrogen in Ryegrass Cultivated on Soil Amended with Commercial Compost. Compost \& Science Utilization, 20, 97-104. http://dx.doi.org/10.1080/1065657X.2012.10737032

[4] Eghball, B. and Power, J. (1999) Phosphorus and Nitrogen Based Manure and Compost Applications: Maize Production and Soil Phosphorus. Soil Science Society of America Journal, 63, 895-901. http://dx.doi.org/10.2136/sssaj1999.634895x

[5] Eghball, B. (2000) Nitrogen Mineralization from Field-Applied Beef Cattle Feedlot Manure or Compost. Soil Science Society of America Journal, 64, 2024-2030. http://dx.doi.org/10.2136/sssaj2000.6462024x

[6] Hartz, T.K., Mitchell, J.P. and Giannini, C. (2000) Nitrogen and Carbon Mineralization Dynamics of Manures and Compost. HortScience, 35, 209-212.

[7] Fortun, C. and Fortun, A. (1995) Effects of Composted Sewage Sludge on the Residual Ion Content of Soils. Agrochimica, 39, 53-60.

[8] Hirzel, J., Matus, I., Novoa, F. and Walter, I. (2007) Effect of Poultry Litter on Silage Maize (Zea mays L.) Production and Nutrient Uptake. Spanish Journal of Agricultural Research, 5, 102-109. http://dx.doi.org/10.5424/sjar/2007051-226

[9] Pang, X.P. and Letey, J. (2000) Organic Farming: Challenge of Timing Nitrogen Availability to Crop Nitrogen Requirements. Soil Science Society of America Journal, 64, 247-253. http://dx.doi.org/10.2136/sssaj2000.641247x

[10] Chadwick, D.R., John, F., Pain, B.F., Chambers, B.J. and Williams, J. (2000) Plant Uptake of Nitrogen from the Organic Nitrogen Fraction of Animal Manures: A Laboratory Experiment. The Journal of Agricultural Science, 134, 159168. http://dx.doi.org/10.1017/S0021859699007510

[11] Hirzel, J., Undurraga, P. and Walter, I. (2010) Nitrogen Mineralization and Released Nutrients in a Volcanic Soil Amended with Poultry Litter. Chilean Journal of Agricultural Research, 70, 113-121. http://dx.doi.org/10.4067/S0718-58392010000100012

[12] Afyuni, M. and Schulin, R. (2002) Repetitive and Residual Effects of Sewage Sludge Application on Extractability and Plant Uptake of $\mathrm{Cu}, \mathrm{Zn}, \mathrm{Pb}$ and $\mathrm{Cd}$. Proceedings of 12th International Soil Conservation Organization Conference, Beijing, 26-31 May 2002, 250-255.

[13] Gascho, G.J., Hubbard, R.K., Brenneman, T.B., Johnson, A.W., Sumner, D.R. and Harris, G.H. (2001) Effects of Broiler Litter in an Irrigated, Double-Cropped, Conservation-Tilled Rotation. Agronomy Journal, 93, 1315-1320. http://dx.doi.org/10.2134/agronj2001.1315

[14] Pierzynski, G.M. (1994) Plant Nutrient Aspects of Sewage Sludge. In: Clapp, C.E., Larson, W.E. and Dowdy, R.H., Eds., Sewage Sludge: Land Utilization and the Environment, SSSA Miscellaneous Publication, Madison, 21-25.

[15] Pederson, G.A., Brink, G.E. and Fairbrother, T.E. (2002) Nutrient Uptake in Plant Parts of Sixteen Forages Fertilized with Poultry Litter: Nitrogen, Phosphorus, Potassium, Copper, and Zinc. Agronomy Journal, 94, 895-904. http://dx.doi.org/10.2134/agronj2002.8950

[16] Martínez, F., Cuevas, G., Calvo, R. and Walter, I. (2003) Biowaste Effects on Soil and Native Plants in a Semiarid Ecosystem. Journal of Environmental Quality, 32, 472-479. http://dx.doi.org/10.2134/jeq2003.4720

[17] Walter, I., Martínez, F., Alonso, L. and de Gracia Gabriela Cuevas, J. (2002) Extractable Soil Heavy Metals Following the Cessation of Biosolids Application to Agricultural Soil. Environmental Pollution, 117, 315-321. http://dx.doi.org/10.1016/S0269-7491(01)00181-6

[18] Pascual, I., Antolín, M.C., García, C., Polo, A. and Sánchez-Díaz, M. (2005) Plant Availability of Heavy Metals in a Soil Amended with a High Dose of Sewage Sludge under Drought Conditions. Biology and Fertility of Soils, 40, 291299. http://dx.doi.org/10.1007/s00374-004-0763-1

[19] USDA (1994) Reference to Soil Taxonomy. USDA, Washington DC.

[20] CIREN (1999) Descripciones de suelos materiales y símbolos: Estudio Agrológico VIII Región. Publicación Ciren No. 121, Santiago, 583 p.

[21] CIREN (1983) Descripciones de suelos: Estudio Agrológico VII Región. Publicación Ciren No. 45, Santiago, 186 p.

[22] Tisdale, S., Nelson, W., Havlin, J. and Beaton, J. (1999) Soil Fertility and Fertilizers. An Introduction to Nutrient Management. 6th Edition, Prentice-Hall, Upper Saddle River, 503 p.

[23] SAS Institute (1989) Usage and Reference. Version 6, SAS Institute Inc., Cary, 501 p.

[24] Box, G. and Cox, D. (1964) An Analysis of Transformations. Journal of the Royal Statistical Society. Series B (Methodological), 26, 211-252.

[25] Etchevers, J. and Padilla, J. (2007) Diagnóstico de la Fertilidad del Suelo. In: Alcántar y Trejo-Téllez, Ed., Nutrición de cultivos, Ediciones Mundi-Prensa, México.

[26] Hirzel, J., Leon, L., Flores, F. and Cerda, F. (2013) Manure-Based Organic Soil Amendments Provide an Adequate 
Nutritional Source for Corn Production in Chile When Combined with Urea Applications. Compost Science \& Utilization, 21, 134-146. http://dx.doi.org/10.1080/1065657X.2013.859529

[27] Benton, J. (1998) Plant Nutrition Manual. CRC Press LLC, Washington.

[28] Cuevas, G. and Walter, I. (2004) Metales Pesados en Maíz (Zea mays L.) Cultivado en un Suelo Enmendado con Diferentes Dosis de Compost de Lodo Residual. Revista Internacional de Contaminación Ambiental, 20, 59-68.

[29] Sims, J.T. and Wolf, D.C. (1994) Poultry Waste Management: Agricultural and Environmental Issues. Advances in Agronomy, 52, 1-83. http://dx.doi.org/10.1016/S0065-2113(08)60621-5

[30] Fernández, M. (1995) Fertilización Nitrogenada y su Eficiencia en Maíz de Grano. Simiente, 65, 122-132.

[31] Eghball, B. (2002) Soil Properties as Influenced by Phosphorus- and Nitrogen-Based Manure and Compost Applications. Agronomy Journal, 94, 128-135. http://dx.doi.org/10.2134/agronj2002.0128 